\title{
DOES DIRECT DEMOCRACY MATTER FOR POLITICAL PARTIES?
}

\author{
An Empirical Test in the Swiss Cantons
}

\author{
Andreas Ladner and Michael Brändle
}

\begin{abstract}
According to most political scientists and commentators, direct democracy seems to weaken political parties. Our empirical analysis in the 26 Swiss cantons shows that this thesis in its general form cannot be maintained. Political parties in cantons with extensive use of referendums and initiatives are not in all respects weaker than parties in cantons with little use of direct democratic means of participation. On the contrary, direct democracy goes together with more professional and formalized party organizations. Use of direct democracy is associated with more fragmented and volatile party systems, and with greater support for small parties, but causal interpretations of these relationships are difficult.
\end{abstract}

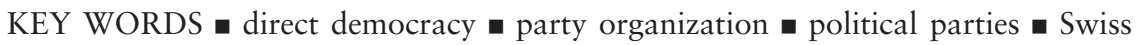
cantons

Direct democracy has become more and more popular in the last few years. ${ }^{1}$ Especially since the 1970s the use of referendums has increased (Kobach, 1993: 4ff.; Butler and Ranney, 1994: 5) ${ }^{2}$ and a growing number of voices describe direct democracy as a panacea for increasing disenchantment with politics, politicians and political parties. ${ }^{3}$ Accordingly, questions concerning the influence of direct democracy on different elements of the political system and on the political culture have become of vital interest.

Switzerland provides an excellent laboratory for analysing these questions. It is not only the country with the most far-reaching possibilities for direct democracy but is also, at least on a national level, the world leader in the use of direct democracy (Trechsel and Kriesi, 1996: 185): from its foundation in 1848 until the end of 1996 not less than 433 ballot issues have been put forward nationwide. That is more than all other countries 
combined since the emergence of the modern nation-state (Kobach, 1996: 98). And, due to the Swiss federalist structure with 26 quite different and politically autonomous cantons, there are considerable differences in regard to both the practice of direct democracy and various aspects of the political systems and the political culture. Surprisingly, there has up to now been little thorough research regarding the impact of direct democracy upon the political system (Kobach, 1993: 7) and political processes. This is especially true as far as empirical studies are concerned. ${ }^{4}$

This paper deals with the interrelations between direct democracy and different variables concerning political parties and the party system, subsumed under the term 'party strength'. In particular, it tries to answer the question of whether direct democracy weakens political parties, as the majority of observers of direct democracy in the American states and in Switzerland tend to argue (Budge, 1996: 120).

\section{Direct Democracy and Political Parties: The Traditional View}

Despite the lack of empirical research and results, there is astonishingly wide agreement among political scientists and observers about the influence of direct democracy on political parties and the party system: direct democracy basically seems to weaken political parties, although it might have some minor positive effects on parties as well. However, most of these observations are based on the national level. In Switzerland, national-level parties resemble umbrella organizations, lacking financial resources and having difficulties putting forward a coherent political profile and ensuring the support of all the cantonal sections. And it is precisely this organizational weakness at a national level that is very often more or less directly implied when the various authors refer to weak Swiss parties.

One set of arguments finds its roots in the work of Gruner (1964, 1977, 1984) and is based on the aspects of mobilization of voters and of party ties. According to Gruner (1984: 149), direct democracy, among all institutional characteristics of the Swiss political system, has been of the utmost importance to political parties. Nevertheless, the influence has been ambiguous: direct democracy seems to be responsible for the early emergence as well as for the relative weakness of Swiss political parties. Parties are commonly called 'children of democratic rights' (Kinder der Volksrechte) as their formation is strongly connected with the successful claim for direct democratic rights; that is, the general and direct elections, the constitutional and legislative referendum, and the constitutional initiative. The oldest political parties were founded in those cantons that already knew early forms of the referendum - the popular veto or the right of recall (Gruner, 1964: 273).5 But direct democracy also allows party leaders to mobilize a large number of their supporters rapidly and without great effort, because these supporters are ready to be mobilized for ideological 
reasons anyway when controversial political questions are at stake. Political parties are therefore not forced to build up a strong organizational structure with highly committed adherents. They can rely on a small cadre not falling back into lethargy after a ballot campaign and mobilizing the masses again when necessary (Gruner, 1977: 27f.). Therefore, in the eyes of Gruner, it is not a paradox that the Swiss political parties were among the first mass or popular parties and at the same time only created weak party organizations.

Another set of arguments considers the role of political parties in the decision-making process at different stages and the importance of other intermediary organizations. Some of the reasoning can be traced back to the work of Neidhart (1970). In a direct democratic system the possibility of blocking any decision by questioning the government's proposals through a referendum makes thorough negotiation between the various interests involved absolutely necessary. It is basically the threat of a referendum that can endanger a carefully arranged compromise after its deliberation in parliament that has fundamentally changed Swiss democracy from a true plebiscitarian democracy to one characterized by negotiation. Here, it is not the political parties but the generally much more homogenous interest groups that play a crucial role in the increasingly important pre-parliamentary process of negotiation, as well as during a referendum. Or, in the words of Neidhart (1986: 43): direct democracy demonopolizes and defunctionalizes political parties as much as the process of interest articulation; opposition and legitimacy of decision follow an independent logic. Beyme (1982: 228) also argues, with a special nod to Switzerland, that the Referendumsdemokratie has favoured interest organizations rather than political parties. In the course of a campaign, interest organizations mobilize for a ballot more efficiently than political parties, which have to pay attention to their consociational partners in the cartel of political representation.

Among the more recent publications, Kobach (1993: 122) seems particularly convinced about the negative impact of direct democracy upon Swiss political parties. He states that 'all four governing parties rose to power by taking a formidable dose of direct democracy. Although the injection worked, the continuing presence of the drug has left the parties substantially weakened'. According to Kobach, the parties' role has diminished with regard to the expression of issue preferences to the electorate, the aggregation of interests, and the setting of political agendas.

Budge (1996: 120-4) is much more positive about the impact of direct democracy on political parties, maintaining that many of the arguments about weakening effects are contradictory and quite often based on the effects on dominant parties. For him, the vitalizing effect on party systems and on the emergence of new parties or new issues, which enforce the responsiveness of established parties, are usually underestimated.

The bulk of arguments postulating the negative effects of direct democracy on political parties in general or at least upon the parties in power can be summarized in four points. 
- Competition: Direct democracy fosters competition with governing political parties by aiding political pressure groups and new and oppositional parties. Since direct democracy allows political groups to move the masses more easily, political parties no longer monopolize politics. Social movements, single-issue and interest groups are also able to influence the political agenda directly. These groups even have some advantages over political parties (Kriesi, 1986: 338; Möckli, 1994: 234). Because the political system needs to find a broadly acceptable consensus, interest groups are much more directly integrated into the pre-parliamentary process, and are financially stronger. And it is easier for single-issue groups to use direct democracy to promote a clear-cut political position than it is for the ideologically less focused political parties. Whereas the political parties in general are threatened by other political groups, the established political parties are additionally threatened by new and oppositional parties since direct democracy makes it easier for them to enter the political system and put forward their demands.

- Conflict: Direct democracy induces conflicts between political parties in various ways. First of all, they are constantly forced to decide on specific issues. A party is thus continuously tested as to whether or not it sticks to its principles and its party programme. It must make considerable efforts to justify its position on ballot issues to voters as well as to its own rank and file. Since most of the parties are heterogeneous and weakly organized, consisting of rather autonomous cantonal sections, concrete decisions on political issues also create the potential for intra-party conflict (see also Möckli, 1994: 234). For example, it is not uncommon for cantonal parties to take a different stand from their national affiliates (Gruner and Hertig, 1983: 125; Hug, 1994: 89). Here, the argument is easy to make that Swiss political parties are rather weak because they are unable to agree on certain decisions. ${ }^{6}$ Party organizations need a democratic or at least legitimate process of decision-making, which might weaken their ability to operate.

- Extra work: Confronted with a growing number of ballots, political parties only play a minor role (Gruner, 1984: 150). Without strong organizational ties they lack financial resources, know-how and volunteers. Compared to other countries, direct democracy imposes extra work on the Swiss political parties. ${ }^{7}$ Since the parties lack money and professional staff, they are unable to take the lead on every ballot issue. Because of their more general orientations, parties are forced to deal with all propositions, whereas interest groups only concentrate on questions within their specific field of concern. This point, of course, is directly related to the financial situation of the Swiss parties, and would lose much of its explanatory power if the parties were given enough resources.

- Annibilation - party intermediation becomes obsolete: The political culture of direct democracy makes the organization of society into parties more difficult and fosters genuine anti-party feelings (Neidhart, 1986: 43). This argument is supported by the fact that elections in Switzerland 
have a low and decreasing turnout and are considered of lesser importance. It does not really matter who gets elected, as the citizens do not lose control over important political decisions.

Political parties are also said to gain some advantages from the system of direct democracy:

- Openness of the political system: A direct democratic system favours new and smaller political parties (see, for example, Papadopoulos, 1991, 1996; Möckli, 1994: 239) and new political ideas. ${ }^{8}$ This is a plus as long newcomers do not lead the party system to collapse, but rather stimulate political competition. Opposition to the government may also be absorbed and productively channelled into accepted forms of political participation. For non-governmental parties, direct democracy offers a well-defined way of interest articulation. The referendum in particular enables smaller parties, which in majority elections have little chance of gaining a seat, to remain influential. They can use the threat of a referendum to blackmail a governing coalition, or can use direct democracy to keep their issues on the political agenda even if their electoral success is fading. Thus, direct democracy supports the survival of the smaller parties (Gruner, 1964: 282). But it is not only the smaller and oppositional parties that might take advantage of direct democracy. Direct democracy also constantly forces the established parties to deal with new issues. Political parties may thus be more responsive and therefore better able to cope with social change.

- Platform: Direct democracy gives the parties a good opportunity to put forward their political ideas. Three or four times a year they are offered a platform (see for example Neidhart, 1986: 43). Their positions are reported in all newspapers and their leaders frequently appear on television. This platform effect is somewhat diminished by the large number of parties involved in the Swiss multi-party system, as well by the fact that members of a single party are sometimes found on both the pro- and contra-committees. But it works most effectively when one single party stands against all the others, or at least takes a special position among its usual coalition partners. ${ }^{9}$

- Helps parties maintaining a high level of political activity: Because of direct democracy, Swiss political parties are constantly forced to remain at a relatively high level of political activity. It is not only once every 4 years that the parties have to become active, but throughout the year; decisions have to be taken, information meetings have to be organized and party ideological points of view have to be applied. Party headquarters might profit from the frequent ballots to keep in contact with their branches and organizations on lower political levels. And campaigning might be a good opportunity for mobilizing members and bringing the parties' principles to the people. However, Swiss parties' constant lack of resources weakens these positive effects on their internal mobilization. And, as the money raised for a ballot campaign usually goes to the ballot committee and not 
to the party's office, the mobilization potential and the degree of activity cannot be easily transformed into constant organizational strength.

- Pressure relief valve in a consociational system: The last positive effect on political parties attributed to direct democracy is closely connected to the Swiss consensus system. As all the important parties are usually integrated into the government, initiatives and referendums play the role of a 'pressure relief valve'. It is not uncommon that a governmental party organizes a referendum against a law that was put forward and supported by its party members in government. Although this is usually criticized as a lack of loyalty, there is hardly any reason why a coalition party should abstain from doing so occasionally. Initiatives and referendums enable governmental parties to act independently of the parties they share power with and this can help to break the chains of consociationalism. It also reduces the pressure on the voters to defect from their parties over particular issues.

It is very difficult to weigh up all these arguments to estimate the effective influence of direct democracy upon political parties. Although many political scientists express a rather mystifying sympathy for the 'direct-democracy-weakens-political-parties-thesis', clearly what is needed is empirical testing of these supposed effects.

\section{Measuring Direct Democracy and Party Strength}

As already mentioned, in federal Switzerland the national level is not appropriate for testing the influence of direct democracy on party strength. The 26 Swiss cantons provide a much more favourable empirical setting, differing quite considerably in terms of parties and in terms of patterns of direct democracy. But before we are able to empirically address the question of whether direct democracy goes hand in hand with weak political parties, we need a measure for direct democracy that can be applied in the cantons, and we also have to define 'party strength'.

Classifying cantons according to the degree of direct democracy is a contested issue. Three basic approaches are possible: to consider the sheer availability of direct democratic instruments, the accessibility of these instruments, or the degree to which they are used. A first group of classifications is based on institutional provisions for direct democracy. The more different forms of direct democracy and the wider the range of issues to be resolved by direct democratic means, the more directly democratic the canton. Thus, for many political scientists and commentators the German-speaking part of Switzerland is considered more directly democratic than the French- and Italian-speaking parts (see for example Linder, 1991: 50, 1994: 85; Kriesi, 1995: 87). This is partly justified. On the communal level, for example, the French- and Italian-speaking communities favour a parliament, and thus a representative system, and the German-speaking communities a communal 
assembly - a direct democratic legislative system (see Ladner, 1991: 81 ff.). ${ }^{10}$ These preferences also hold for the cantonal level. The German-speaking canton of Zurich, for example, is supposed in this view to be more directly democratic than many others, since it permits the 'citizens initiative' (Einzelinitiative), by which every citizen can launch an initiative when he or she is able to gain the support of 60 of the 180 members of parliament (see Moser, 1985: 52). ${ }^{11}$

The work of Weck-Hannemann and Pommerehne (1996), which covers direct democratic decision-making on fiscal issues, also belongs to this group of classifications. Here, direct democratic cantons are those in which citizens have to approve the tax rate and where the executive or parliament do not alone decide on the budget (see Feld and Savioz, 1996: 6). ${ }^{12}$ In such a view the canton of Zurich does not belong to the group of direct democratic cantons because the tax rate does not have to be approved by the citizens.

Institutional provisions may also distinguish a further group of cantons those that still know the Landsgemeinde (Glaris, Obwalden, Nidwalden, Appenzell-AR, Appenzell-IR). ${ }^{13}$ The Landsgemeinde is a cantonal meeting of all citizens to decide cantonal law-making, elections of judges, the setting of income tax rates and cantonal spending. ${ }^{14}$ Here it is obvious that political parties play a minor role from the beginning and the question is whether these cantons should be treated as special cases or as cantons with the most far-reaching direct democratic facilities. ${ }^{15}$

The institutional possibility of using means of direct democracy is one thing, the conditions under which they can be used is another. What is the point of theoretically having a wide range of possibilities when it is almost impossible to use them because the hurdles are too high? The second group of classifications is thus based on the 'entry price' of direct democracy. This can be measured in terms of the number of signatures required for constitutional initiatives, legislative initiatives and optional referendums as a percentage of the electorate, and the number of days given for the collection of the required signatures (see, for example, Kriesi and Wisler, 1996: 24). ${ }^{16}$

A third and final approach looks at the use of direct democracy. Direct democratic cantons are those where the citizens have to decide frequently on ballot issues caused by an initiative or an optional referendum. ${ }^{17}$ The mandatory (obligatory) referendum can be left aside, as it is mainly due to institutional provisions and has little to do with the political actors involved.

Until now, little statistical evidence has been put forward that in cantons with high 'entry hurdles' (in terms of the absolute number of signatures required, the number of signatures in relation to the number of voters, or the time allowed for collection of signatures) referendums or initiatives are used less (Linder, 1994: 88). Our data (see Table 1) also show that there is no strong correlation ${ }^{18}$ between the use of direct democracy and the entry hurdles or institutional provisions (i.e. the facilities enabling citizens to decide on fiscal issues or the language area). ${ }^{19}$ Strong correlations do exist between entry hurdles and institutional differences, such as the possibility 
Table 1. Different classifications of direct democracy (Pearson correlation coefficients)

\begin{tabular}{|c|c|c|c|c|}
\hline & Use & Hurdles & Finance & Language $\mathrm{a}^{\mathrm{a}}$ \\
\hline Use of direct democracy & & .16 & .06 & -.08 \\
\hline Entry hurdles & .16 & & .42 & .65 \\
\hline Institution: finance issues & .06 & .42 & & .29 \\
\hline $\begin{array}{l}\text { Institutions: German- vs French/Italian- } \\
\text { speaking cantons }\end{array}$ & -.08 & .65 & .29 & \\
\hline
\end{tabular}

of deciding on fiscal issues and the differences between the language areas. In other words: German-speaking cantons have more direct democratic facilities for deciding on fiscal issues and the entry price for using direct democracy is lower.

For our empirical analyses we work with the effective use of direct democracy, measured as the number of initiatives and optional referendums voted on between 1991 and 1996. In other words, we consider political reality to be more important than mere institutional availability in regard to anticipated effects on political parties and the party system. Why should the sheer possibility of direct democratic participation weaken the political parties when there are no political actors able or willing to use them? The only possible argument against this would have to use Neidhart's reasoning that at the pre-parliamentary stage of decision-making the threat of a referendum is most effective when it does not come to a referendum. This might be partly true, but only holds for referendums and does not account for initiatives. Furthermore, every threat loses its power when there are signs that it cannot be carried out. We are aware, however, that one consequence of employing a usage variable is that we can be less sure about the causality of the relation between direct democracy and party strength. ${ }^{20}$

There are a few other variables expected to have an influence on both political parties and the use of direct democracy. Such variables include: the size of the canton (inhabitants), the average size of the communities in a canton, the number of communities in a canton, the degree of urbanization and the language area (German- or French- and Italian-speaking cantons). As is shown in Table 2, urbanization and larger community size, and to a lesser extent larger cantonal size, are associated with a greater use of initiatives and referendums. For our test we therefore have to control at least for urbanization and the average size of communities.

The Swiss party system offers, as already mentioned, almost ideal conditions for empirical analyses. As a consequence of the federalist structure Swiss parties are strongly rooted at the local and cantonal level. There are 
Table 2. 'Control variables' and direct democracy (Pearson correlation coefficients)

\begin{tabular}{ll}
\hline & Use of direct democracy \\
\hline Number of communities & .11 \\
Average size of communitites & .72 \\
Size of the canton & .41 \\
Urbanization $^{\mathrm{a}}$ & .70 \\
Language $^{\mathrm{L}}$ & .08 \\
\hline a 0 = rural cantons; i.e. UR, SZ, OW, NW, GL, FR, SO, SH, AR, AI, GR, AG, TG, VS, NE and \\
JU. \\
1 = urban cantons; i.e. ZH, BE, LU, ZG, BS, BL, SG, TI, VD, GE. \\
b = German-speaking; i.e. ZH, BE, LU, UR, SZ, OW, NW, GL, ZG, SO, BS, BL, SH, AR, AI, \\
SG, GR, AG and TG. \\
1 = French/Italian-speaking; i.e. FR, TI, VD, VS, NE, GE, JU.
\end{tabular}

more than 150 parties and political groups at the cantonal level, and nearly 6000 at the local level (Ladner, 1996: 134). Their number, kind and importance vary from canton to canton and it is not uncommon to speak of 26 different cantonal party systems within the country. Hence, whether or not direct democracy goes hand in hand with weak political parties is an empirical question.

Much of the problem in judging how direct democracy affects political parties is the lack of clear concepts for evaluating party strength (Budge, 1996: 121). The term 'party strength' contains different elements, including party organization, the influence of political parties and the party system as a whole. For our empirical evaluation we propose using nine different variables which are more or less linked to the idea of party strength. ${ }^{21}$ The nine variables measured either at the cantonal or the local level can be divided into three groups:

1 Strength of party organization:

- formalized party membership (percentage of local party organizations applying formal membership criteria and being able to distinguish between party members and adherents);

- percentage of communities having organized political parties;

- professionalization of party organizations (paid party staff);

- party membership within the cantons (percentage of party members in the electorate).

2 Influence of parties:

- percentage of local councillors affiliated with a party;

- influence of local political parties according to communal secretaries.

3 Shape of the party system:

- fractionalization (Rae Index);

- volatility (based on the percentage of seats in the cantonal parliament); 
Table 3. Control variables and 'party strength' (Pearson correlation coefficients)

\begin{tabular}{|c|c|c|c|c|c|c|c|c|c|}
\hline Variable & $\begin{array}{l}\text { Formal- } \\
\text { ization }\end{array}$ & $\begin{array}{l}\text { Local party } \\
\text { organizations }\end{array}$ & $\begin{array}{l}\text { Professional- } \\
\text { ization }\end{array}$ & $\begin{array}{l}\text { Party } \\
\text { membership }\end{array}$ & $\begin{array}{l}\text { Party affili- } \\
\text { ates in local } \\
\text { executives }\end{array}$ & $\begin{array}{l}\text { Perceived } \\
\text { party } \\
\text { influence }\end{array}$ & $\begin{array}{l}\text { Strength of non- } \\
\text { governmental } \\
\text { parties }\end{array}$ & $\begin{array}{l}\text { Fractional- } \\
\text { ization }\end{array}$ & Volatility \\
\hline No. of communitites & .03 & -.34 & .06 & .03 & -.36 & -.29 & -.03 & .30 & -.14 \\
\hline Size of canton & .32 & .02 & .37 & .09 & -.08 & .06 & .31 & .41 & .28 \\
\hline Urbanization & .36 & .22 & .60 & -.05 & .15 & .32 & .47 & .37 & .51 \\
\hline Language area & -.36 & -.20 & .06 & -.23 & -.24 & -.14 & .09 & .06 & .18 \\
\hline
\end{tabular}


- influence of smaller parties (percentage of seats of 'non-governmental' parties in cantonal parliament; i.e. all parties except FDP, CVP, SVP, SPS and LPS).

The four variables measuring the organizational strength of a party are rather independent from each other (see Appendix, Table A1). An important correlation exists only between the degree of formalization and party membership. On the other hand, the two variables measuring the influence of political parties in a canton are strongly linked. The percentage of partyaffiliated local councillors is positively associated with the influence of political parties as perceived by communal secretaries. Both variables are also positively associated with the percentage of communities with local party organization. The latter is also significantly connected with the degree of professionalization.

The three party system variables also correlate with each other. The higher the percentage of seats held by 'non-governmental parties', the more fractionalized and volatile the party system is, while fractionalization and volatility are themselves positively correlated. Basically, a higher degree of formalization and professionalization goes together with a higher percentage of seats for non-governmental parties and high fractionalization and volatility. The two variables measuring party influence seem not to be connected with the party systems variables.

Table 3 includes other variables expected to have an influence on political parties as well as on direct democracy: the size of the canton (inhabitants), the average size of the communities in a canton, the number of communities in a canton, the degree of urbanization, and the language (German- or French/Italian-speaking cantons). Again, the average size of the communities and the degree of urbanization correlate highly with some of the variables measuring party strength. The others seem to be of lesser influence.

\section{Direct Democracy and Party Strength: Some Empirical Evidence}

This final section brings the use of direct democracy and party strength together. Table 4 shows the results for each group of party strength variables and controls for the average size of communities and for the degree of urbanization. As far as organizational party strength is concerned, two aspects are positively connected with the use of direct democracy: formalization of party organization and professionalization of party staff. Both correlations remain positive even when controlling for the average size of communities, the degree of urbanization or both together. All these correlation coefficients show the reverse of what is expected by those who support the thesis that direct democracy goes hand in hand with weak political parties, at least as far as organization is concerned. Political parties are stronger in terms of formalized membership and professionalization in cantons that are more 
Table 4. Use of direct democracy and strength of party organization

\begin{tabular}{|c|c|c|c|c|}
\hline Variable & $\begin{array}{l}\text { Initiatives } \\
\text { and } \\
\text { referendums } \\
1991-6 \\
\text { (Pearson corr.) }\end{array}$ & $\begin{array}{l}\text { Controlled } \\
\text { for average } \\
\text { size of } \\
\text { commune } \\
\text { (Partial corr.) }\end{array}$ & $\begin{array}{l}\text { Controlled } \\
\text { for } \\
\text { urbanization } \\
\text { (Partial corr.) }\end{array}$ & $\begin{array}{l}\text { Controlled } \\
\text { for size of } \\
\text { communities } \\
\text { and } \\
\text { urbanization } \\
\text { (Partial corr.) }\end{array}$ \\
\hline \multicolumn{5}{|l|}{ Strength of party organization } \\
\hline Formalized membership & .56 & .34 & .47 & .26 \\
\hline $\begin{array}{l}\text { Percentage of local } \\
\text { party organizations }\end{array}$ & .11 & -.28 & -.28 & -.47 \\
\hline Professionalization & .74 & .55 & .54 & .33 \\
\hline Party membership & -.16 & -.15 & -.22 & -.17 \\
\hline \multicolumn{5}{|l|}{ Influence of parties } \\
\hline \multicolumn{5}{|l|}{ Percentage of local councillors } \\
\hline Influence of political parties & .30 & -.25 & .05 & -.48 \\
\hline \multicolumn{5}{|l|}{ Shape of the party system } \\
\hline $\begin{array}{l}\text { Percentage of seats held by } \\
\text { 'non-governmental parties' }\end{array}$ & .85 & .72 & .82 & .69 \\
\hline Fractionalization & .63 & .64 & .56 & .63 \\
\hline Volatility & .78 & .66 & .69 & .56 \\
\hline
\end{tabular}

directly democratic or, according to our concept of direct democracy, where direct democracy is used more often. Since there is no important correlation between the formalization of party membership and professionalization (see Appendix), two different types of party seem likely to go together with an intensive use of direct democracy: a more member-orientated mass party and a more modern electoral professional party.

On the other hand, in cantons where direct democracy is used more often parties have comparatively fewer members and fewer local sections. If we remember Gruner's argument that direct democracy prevents political parties from building up strong organizational structures with highly committed adherents, these results show that he was at least partly wrong. Nevertheless, we might share his reasoning without accepting his conclusion about the negative influence on party strength. The more referendums and initiatives are used, the more often the masses have to be moved. It is apparently more efficient for the parties to have mobilization done by professional party staff. The more ballots are put forward, the more likely a party will try to employ a full-time party secretary. And if parties have to decide on ballot issues frequently and do it in a democratic manner, they favour a clear criterion like formalized membership stating exactly who is entitled to take part in the intra-party decision process and who is not. But direct democracy does not have a mobilizing effect for the parties. It does not help them to increase membership figures or to enlarge their network of local branches. Of course, with all these relations the causation is not very clear. It can also be argued 
that it is the other way round, with well-organized parties launching more initiatives and referendums. In any case, however, this evidence shows that direct democracy does not go together with weak party organization in general.

Let us now turn to the relationship between direct democracy and party influence on politics. Here again, the expected relation is not immediately evident. Political parties are neither significantly weaker nor stronger than in cantons with greater use of direct democracy. But if we control for the average size of the communities and urbanization, direct democracy does seem to correspond with less influence for political parties. Of course, it can be argued that the number of seats held by political parties in local government or the perceived influence of parties in the eyes of communal secretaries are inadequate variables for measuring the influence of political parties in a canton. Admittedly, it would be best to include measures of party influence throughout the whole political process (policy formulation, parliamentary and governmental decisions, executive action, etc.). Still, we are inclined to rely on these data since it seems unlikely that parties are at the same time very much present and influential in the communities without having any influence in cantonal politics. And again, we cannot be sure about the causation of this relation. It remains an open question, whether direct democracy is used more frequently in some communities because there are no influential parties, or whether the parties lack influence because they are sidelined by direct democracy.

Finally, let us look at the correlations between direct democracy and different elements of the cantonal party systems. Here, all correlations are strong, remaining so when controlled for by the average size of communities, the degree of urbanization and both. The fact that all three correlations are found to be important is not astonishing, since all three variables describing the party system are strongly intercorrelated (see Appendix). Frequent use of direct democracy goes together with a high percentage of seats held by smaller parties and a fractionalized and volatile party system. These results support various authors' assertions about the positive influence of direct democracy on new, smaller and oppositional parties (see above). Direct democracy makes a political system more open to new and oppositional parties. The question here is whether this really should be described as weakening the political parties and the party system, since it could also be seen as making them more responsive to social change.

\section{Towards a Better Understanding of the Relation between Direct Democracy and Political Parties}

This paper's empirical test in the 26 Swiss cantons makes it clear that direct democracy matters for political parties. But the widespread thesis that direct democracy weakens parties can, in this generalized form, not be maintained. Political parties are not universally weaker in cantons with an extensive use 
of referendums and initiatives. On the contrary, direct democracy seems to go hand in hand with more professional and formalized party organizations. However, it is true that party systems in more direct democratic cantons are more fragmented and volatile than elsewhere, that smaller parties get a larger share of the vote, and that the influence of political parties seems to be lower in cantons with an extensive use of direct democracy. Nevertheless, we have to be careful about assigning causation in these relations. The use of direct democracy could also be a product of well-organized and influential parties in a competitive and volatile multi-party system.

However, trying to estimate the influence of direct democracy on political parties confronts us with serious methodological problems. First of all, there is the question of how to measure party strength. As our results show, different aspects of party strength are affected differently by direct democracy. It is therefore essential to specify what is meant by party strength. To establish an overall index of party strength that can be used for comparative analyses seems to us rather problematic. Second, clear concepts for measuring direct democracy are missing. Is it, for example, the institutional provisions or their effective use that makes a political system more directly democratic? In this paper we have argued that effective use is more important in influencing and shaping political actors. Third, there is the problem of how to approach these questions comparatively. The Swiss cantons seem to be a good area for research, as the cantonal parties are relatively autonomous and they differ in terms of direct democracy. But what about the effects at the national level? At present, an empirical analysis of this kind at the national level seems almost impossible, as there are hardly enough comparable cases.

Our analysis has additional shortcomings when it comes to causal interpretations. What is sometimes presented as evidence of influence is, of course, statistically nothing more than a coincidence. We are inclined to accept that direct democracy leads to a fragmented party system and we are able to provide good arguments, but theoretically it could also be the number of parties that has led to more extensive use of direct democracy. Here, a historical approach would be more appropriate. And as far as our analytical model is concerned, it is far from being exhaustive. Some variables are missing, such as the degree of inclusiveness of the consociational government, and indirect effects are neglected. In addition, it is impossible to factor in the original effects of direct democracy that made power-sharing and pre-parliamentary negotiations part of the political process.

Further and more thorough research is doubtless needed to determine the real influence of direct democracy on political parties. Nevertheless, this study makes it clear that in the Swiss case at least, direct democracy should not automatically be held responsible for comparatively weak parties, at least as far as organizational aspects are concerned. Other and better explanations have to be found, such as social and cultural heterogeneity and cross-cutting cleavages, together with very strong federalism and the system of consociationalism. 


\section{Appendix}

Table A1. Correlation matrix 'party strength' (Pearson correlation coefficients)

\begin{tabular}{|c|c|c|c|c|c|c|c|c|c|}
\hline & $\begin{array}{l}\text { Formal- } \\
\text { ization }\end{array}$ & $\begin{array}{l}\text { Local party } \\
\text { organizations }\end{array}$ & $\begin{array}{l}\text { Professional- } \\
\text { ization }\end{array}$ & $\begin{array}{l}\text { Party } \\
\text { membership }\end{array}$ & $\begin{array}{l}\text { Party affili- } \\
\text { ates in local } \\
\text { executives }\end{array}$ & $\begin{array}{l}\text { Perceived } \\
\text { party } \\
\text { influence }\end{array}$ & $\begin{array}{l}\text { Strength of non- } \\
\text { governmental } \\
\text { parties }\end{array}$ & $\begin{array}{l}\text { Fractional- } \\
\text { ization }\end{array}$ & Volatility \\
\hline Formalization & 1.00 & .08 & .21 & .42 & -.14 & .06 & .56 & .54 & .56 \\
\hline Local party organ. & .08 & 1.00 & .36 & -.04 & .84 & .92 & .22 & -.25 & .21 \\
\hline Professionalization & .21 & .36 & 1.00 & -.12 & .26 & .56 & .59 & .48 & .54 \\
\hline Party membership & .42 & -.04 & -.12 & 1.00 & -.24 & -.06 & -.25 & -.01 & -.16 \\
\hline $\begin{array}{l}\text { Party affiliates in } \\
\text { local executives }\end{array}$ & -.14 & .84 & .26 & -.24 & 1.00 & .80 & .13 & -.28 & .08 \\
\hline Party influence & .06 & .92 & .56 & -.06 & .80 & 1.00 & .26 & -.18 & .25 \\
\hline $\begin{array}{l}\text { Non-governmental } \\
\text { parties }\end{array}$ & .56 & .22 & .59 & -.25 & .13 & .26 & 1.00 & .68 & .86 \\
\hline Fractionalization & .54 & -.25 & .48 & -.01 & -.28 & -.18 & .68 & 1.00 & .68 \\
\hline Volatility & .56 & .21 & .54 & -.16 & .08 & .25 & .86 & .68 & 1.00 \\
\hline
\end{tabular}




\section{Notes}

This is a revised version of the paper prepared for the 25th ECPR Joint Sessions in Bern, 27 February-4 March 1997, workshop No. 7 'Plebiscitary Politics and Political Parties'. We are especially grateful to both organizers, Susan Scarrow and Pat Seyd, who encouraged us to consider our data under the above aspects and made many important suggestions concerning this final version. We also would like to thank all participants of the workshop and the two anonymous reviewers for their critical and helpful comments.

1 Accordingly, the number of publications on direct democracy has increased considerably (see for example Kobach, 1993; Suksi, 1993; Möckli, 1994; Butler and Ranney, 1994; Luthardt, 1994; Hamon, 1995; Budge, 1996; Gallagher and Uleri, 1996).

2 Mainly responsible for the increase in the use of referendums is Switzerland, and to a lesser extent Egypt and Italy. In the great majority of countries there has been no significant increase (Butler and Ranney, 1994: 4).

3 For Germany see, for example, Alemann (1996: 7f.) and Evers (1991: 8); for the UK see The Economist (21 Dec. 1996).

4 The most systematic and influential analysis of the functions of the Swiss referendum is doubtlessly Neidhart (1970). Newer, although hardly empirical, publications on direct democracy in Switzerland that should be mentioned include Kobach (1993), Papadopulos et al. (1994), Möckli (1994) and the corresponding chapters in Linder (1994), Kriesi (1995), and Brunetti and Straubhaar (1996).

5 The first canton with such rights and political parties founded early was the canton of St Gallen, followed by the cantons of Baselland, Lucerne, Wallis, Waadt and Bern. The movement for an increase in democratic rights reached its peak in the 1860s, when this struggle led to the foundation of left-wing parties, which in various cantons took the name 'Democratic party' (Gruner, 1964: 275).

6 Of course, it could also be argued that this can be functional for the parties, since it offers party members more choice. A party member can either agree with the position of the cantonal party or that of the national party.

7 The former party secretary of the FDP, Christian Kauter, for example, complains that between 1972 und 1993 Swiss political parties had to lead 181 information campaigns in the course of referendums and initiatives as well as five national electoral campaigns (Kauter, 1996: 5f.)

8 Prior to the electoral success of the LdU, the National Right (NA) and new left and green parties, for example, they had established themselves with more or less successful initiative or referendum campaigns (Kriesi, 1986: 338).

9 The recent success of the Swiss People's Party (SVP) is partly due to its clear position in 1992 - compared to its bourgeois political partners, the Radical Democrats (FDP) and the Christian Democrats (CVP) - against Switzerland joining the European Economic Area (EEA) (see Ladner, 1993: 552).

10 Only about $16 \%$ of Swiss communities have a parliament (see Ladner, 1991: 82). In the remainder, citizens come together several times a year in a community meeting to decide on the political issues in question.

11 'Citizens initiatives' also exist in the Landsgemeindekantone Appenzell-AI, Glaris, Nidwalden and Obwalden (see Moser, 1985: 52).

12 According to this classification, the cantons BE, LU, UR, OW, NW, GL, ZG, SO, 
BS, BL, SH, AR, AI, AG, VD, GE, JU are considered more democratic and the cantons ZH, SZ, FR, SG, GR, TG, TI, VS, NE less democratic (see Feld and Savioz, 1996: 7, based on Weck-Hannemann and Pommerehne, 1996).

13 On 1 December 1996, the canton of Nidwalden (NW) abolished the Landsgemeinde. In the canton of Obwalden (OW) a similar proposal was expected to be put to the vote in 1998.

14 For more about Landsgemeinde-Demokratien see, for example, Möckli (1987).

15 The discussion of whether this form of assembly democracy is the most farreaching form of direct democracy is futile. On the one hand, there are good reasons to question the capacities of this model. First of all, obvious limits to this form of legislative decision-making are given by the size of the cantons. The bigger a canton the more difficult it is to bring the people together to discuss and decide. Therefore, second, the normal participation rates are much lower. And third, the ballots are usually not secret, which in some eyes violates a basic general principle of democracy (see for example Luhmann, 1983: 159ff.). On the other hand, an assembly is the place where people can express their political will directly without the aid of intermediate organizations and are still able to influence the questions being put to a decision during the decision process.

16 Although Kriesi and Wisler (1996: 24) argue with the entry price of direct democracy, by ignoring a few exceptions they eventually stick to a distinction between German-speaking cantons and the French/Italian-speaking ones.

17 Correlations considered important are printed in bold letters to make it easier for the reader to locate the numbers discussed in the text. We are especially grateful to Dirk Strohmann of the Année politique suisse at the Institute of Political Science at the University of Bern, who kindly provided us with the data.

18 Since our data cover the universe of all Swiss cantons, there is no reason to add significance levels. Nevertheless, only the stronger correlations are taken into consideration. A correlation of .40 would be significant on a 0.05 level, correlations of .52 and higher on a 0.001 level.

19 This result raises questions about the widespread idea that the French- and Italian-speaking cantons are less inclined to use direct democratic means of participation than the German-speaking ones.

20 If we use for our analyses entry hurdles of institutional provisions, at the very best we will find that there are no important correlations between direct democracy and party strength.

21 The data on the cantonal parties and party systems come from four different research projects: a survey of the communal secretaries of all Swiss communities conducted in 1988 at the Institute of Sociology at the University of Zurich (see Ladner, 1991), a survey of the presidents of about 5500 local parties, conducted in 1990 at the same institute and financed by the Swiss National Fund (see Geser et al., 1994), and another survey of the communal secretaries conducted at the same Institute in 1994 and also financed by the Swiss National Fund. In addition there is a recent research project on Swiss political parties, once more financed by the Swiss National Fund and based at the Institute of Political Science at the University of Bern. 


\section{References}

Alemann, Ulrich von (1996) 'Die Parteien in den Wechsel-Jahren? Zum Wandel des deutschen Parteiensystems', aus Politik und Zeitgeschichte 6: 3-8.

Beyme, Klaus von (1982) Parteien in westlichen Demokratien. München: Piper.

Brunetti, Aymo and Thomas Straubhaar (1996) 'Direkte Demokratie - "bessere" Demokratie? Was lehrt uns das Schweizer Beispiel?’, Zeitschrift für Politikwissenschaft 1: 7-26.

Budge, Ian (1996) The New Challenge of Direct Democracy. Cambridge: Polity.

Butler, David and Austin Ranney, eds (1994) Referenda Around the World. London: Macmillan.

Evers, Tilman (1991) 'Volkssouveränität im Verfahren. Zur Verfassungsdiskussion über direkte Demokratie', aus Politik und Zeitgeschichte 23: 3-15.

Feld, Lars P. and Marcel R. Savioz (1996) 'Direct Democracy Matters for Economic Performance: An Empirical Investigation', Discussion Paper No. 9614, University of St Gallen, Department of Economics.

Gallagher, Michael and Pier Vincenzo Uleri (1996) The Referendum Experience in Europe. Baden-Baden: Nomos.

Geser, Hans, Andreas Ladner, Roland Schaller and Thanh-Huyen Ballmer-Cao (1994) Die Schweizer Lokalparteien. Zürich: Seismo.

Gruner, Erich (1964) 'Eigentümlichkeiten der schweizerischen Parteienstruktur', Politische Vierteljahresschrift 2: 203-17.

Gruner, Erich (1977) Die Parteien der Schweiz. Bern: Francke.

Gruner, Erich und René Hertig (1983) Der Stimmbürger und die neue Politik. Bern: Haupt.

Gruner, Erich (1984) 'Parteien', in Ulrich Klöti (ed.) Handbuch Politisches System der Schweiz, Band 2, pp. 135-62. Bern: Haupt.

Hamon, Francis (1995) Le référendum: Etude comparative. Paris: Libraire générale de droit et de jurisprudence.

Hug, Simon (1994) 'La cohésion des partis fédéraux dans la phase référendaire', in Papadopoulos et al. (eds), pp. 85-112.

Kauter, Christian (1996) 'Das Prinzip der schwachen Parteien', Politische Rundschau 3: 5-12.

Kobach, Kris W. (1993) The Referendum: Direct Democracy in Switzerland. Aldershot: Dartmouth.

Kobach, Kris W. (1996) 'Switzerland', in Butler and Ranney (eds), pp. 98-153.

Kriesi, Hanspeter (1986) 'Perspektiven neuer Politik: Parteien und neue soziale Bewegungen', in Wolf Linder (ed.) Politische Parteien und neue Bewegungen: Schweizerisches Jabrbuch für politische Wissenschaft 1986, pp. 333-50. Bern: Haupt.

Kriesi, Hanspeter (1995) Le système politique suisse. Paris: Economica.

Kriesi, Hanspeter and Dominique Wisler (1996) 'Social Movements and Direct Democracy in Switzerland', European Journal of Political Research 30: 19-40.

Ladner, Andreas (1991) Politische Gemeinden, kommunale Parteien und lokale Politik: Eine empirische Untersuchung in den Gemeinden der Schweiz. Zürich: Seismo.

Ladner, Andreas (1993) 'Switzerland', European Journal of Political Research 24: 547-54. 
Ladner, Andreas (1996) 'Die Schweizer Lokalparteien im Wandel: Aktuelle Entwicklungstendenzen gefährden die politische Stabilität', Schweizerische Zeitschrift für Politische Wissenschaft 2: 1-22.

Linder, Wolf (1991) 'Repräsentative und direkte Demokratie: Systeme im Spannungsverhältnis', in Gemeinderatskommission Wien (ed.) Die Bürger und ibre Stadt. Wien: Forum Stadtverfassung.

Linder, Wolf (1994) Swiss Democracy: Possible Solutions to Conflict in Multicultural Societies. London: St Martin's Press.

Luhmann, Niklas (1983) Legitimation durch Verfahren. Frankfurt: Suhrkamp.

Luthardt, Wolfgang (1994) Direkte Demokratie: Ein Vergleich in Westeuropa. Baden-Baden: Nomos.

Moser, Christian (1985) Die Gesetzgebungsverfahren der Kantone. (Informationsbulletin Nr. 13 der Programmleitung NFP 6.) Bern: Forschungszentrum für schweizerische Politik.

Möckli, Silvano (1987) Die schweizerischen Landsgemeinde-Demokratien. Bern: Haupt.

Möckli, Silvano (1994) Direkte Demokratie: Ein internationaler Vergleich. Bern: Haupt.

Neidhart, Leonhard (1970) Plebiszit und pluralitäre Demokratie: Eine Analyse zur Funktion des schweizerischen Gesetzesreferenda. Bern: Francke.

Neidhart, Leonhard (1986) 'Funktions- und Organisationsprobleme der schweizerischen Parteien', in Wolf Linder (ed.) Politische Parteien und neue Bewegungen. Schweizerisches Jahrbuch für politische Wissenschaft 1986, pp. 21-46. Bern: Haupt.

Papadopoulos, Yannis (1991) 'Quel rôle pour les petits partis dans la démocratie dirécte?', Annuaire suisse de science politique 31: 131-50.

Papadopoulos, Yannis, Simon Hug and William Ossipow (1994) Elites politiques et peuple en Suisse: Analyse des votations fédérales 1970-1987. Lausanne: réalités sociales.

Papadopoulos, Yannis (1996) 'De Charybde en Scylla: Le système politique suisse entre crise de représentation et crise d'adaptation', in Claudia Honegger (ed.) Gesellschaften im Umbau: Identitäten, Konflikte und Differenzen. Hauptreferate des Kongresses der schweizerischen Sozialwissenschaften in Bern 1995, pp. 135-48. Zürich: Seismo.

Suksi, Markku (1993) Bringing in the People: A Comparison of Constitutional Forms and Practices of the Referendum. Dordrecht: Martinus Nijhoff.

Trechsel, Alexander and Hanspeter Kriesi (1996) 'Switzerland: The Referendum and Initiative as a Centrepiece of the Political System', in Gallagher and Uleri (eds), pp. 185-208.

Weck-Hannemann, Hannelore and Werner W. Pommerehne (1996) 'Tax Evasion: An Empirical Analysis', Public Choice 88(1-2): 161-70.

Wiesendahl, Elmar (1980) Parteien und Demokratie: Eine soziologische Analyse paradigmatischer Ansätze der Parteienforschung. Opladen: Westdeutscher Verlag.

ANDREAS LADNER formerly worked at the Institute of Sociology at the University of Zurich. He is now a lecturer at the Institute of Political Science, University of Bern. His research focuses on political communities, political participation and 
political parties. Currently he leads two research projects financed by the Swiss National Science Foundation, one on the development of Swiss party organizations and the other on on-going reform processes at local level.

ADDRESS: Institut für Politikwissenschaft, Universität Bern, Lerchenweg 36, 3000 Bern 9, Switzerland. [email: andreas.ladner@ipw.unibe.ch]

MICHAEL BRÄNDLE is a research assistant at the Institute of Political Science, University of Bern. His research focuses on party organizations and party democracy. $\mathrm{He}$ is a participant in the current research project on the development of Swiss party organizations. In addition, he collected and analysed the data on the Swiss parties for the European Party Manifesto Project.

ADDRESS: Institut für Politikwissenschaft, Universität Bern, Lerchenweg 36, 3000 Bern 9, Switzerland. [email: michael.braendle@ipw.unibe.ch]

Paper submitted 15 September 1997; accepted for publication 10 April 1998. 